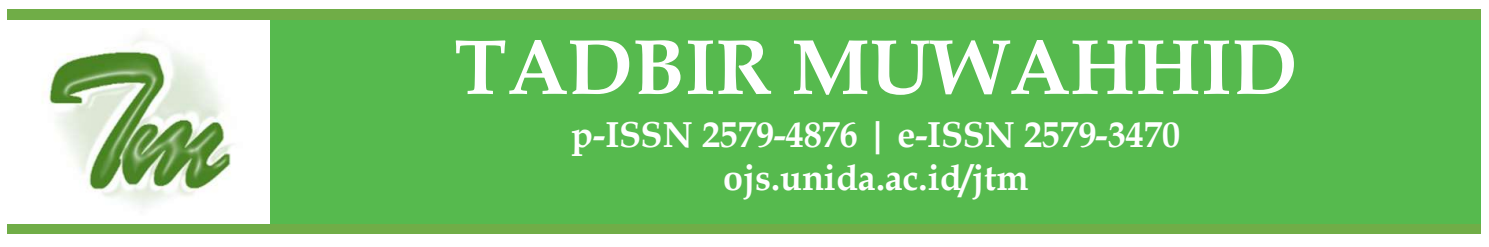

\title{
Konsep Manusia dalam Epistemologi Kepemimpinan
}

\author{
Radif Khotamir Rusli ${ }^{1}$, Hasbi Indra ${ }^{2}$ \\ 1. Program Studi Pendidikan Bahasa Arab, Fakultas Keguruan dan Ilmu Keguruan \\ Universitas Djuanda Bogor \\ Jl. Tol Jagorawi No. 1 Ciawi, Bogor \\ 2. Sekolah Pascasarjana Program Doktor Pendidikan Agama Islam \\ Universitas Ibn Khaldun Bogor \\ Jl. Sholeh Iskandar, Kedungbadak, Kec. Tanah Sereal, Bogor
}

Volume 4 Nomor 2

Oktober 2020: 203-232

DOI: $10.30997 / \mathrm{jtm} . v 4 \mathrm{i} 2.3084$

Article History

Submission: $18-07-2020$

Revised: 18-08-2020

Accepted: 19-10-2020

Published: 28-10-2020

Kata Kunci:

Manusia, Kepemimpinan, Pendidikan Islam, Epistemology

Keywords:

Manusia, Leaderhsip, Islamic

Education, Epistemology

Korespondensi:

Radif Khotamir Rusli

082124978983

radif.kr@unida.ac.id
Abstrak: Menjadi pemimpin adalah satu satu fungsi eksistensi manusia di muka bumi ini, walaupun secara biologis, naluriah manusia bukanlah makhluk yang jauh berbeda dengan hewan yang hidup berkembang biak selayaknya mamalia yang mengandung, melahirkan, dan menyusui. Namun demikian, dalam sekelompok spesies tertentu seperti kera misalnya, memiliki ketua atau pimpinan yang dipatuhi oleh kelompoknya. Bahkan, kerumunan semut atau lebah akan senantiasa tunduk patuh terhadap ratu-nya untuk tetap mempertahankan keberlangsungan hidup koloninya. Tidak berbeda dengan manusia, tentunya sejak diciptakan Adam sebagai manusia pertama, Allah SWT telah membekali manusia dengan kapasitas tertentu sebagai suatu sistem keberlangsungan hidup manusia sehingga manusia terjaga dan lestari walaupun telah terjadi berbagai tragedi di dalam sejarah, jika dibandingkan dengan zaman prasejarah, dinosaurus telah punah ditelan masa. Penelitian ini bertujuan untuk menguraikan konsep pemimpin dan kepemimpinan beserta teori, fungsi dan faktor-faktornya yang mengetengahkan epistemologi Kepemimpinan khususnya terkait Pendidikan Agama Islam sebagai Agama fitrah. Tulisan ini menggunakan pendekatan kualitatif dengan metode studi dokumentasi. Hasil pengkajian menemukan bahwa manusia dianugerasi potensi untuk mengembangkan diri dan menjadi seorang pemimpin dilingkungannya. Menjadi seorang pemimpin pada dasarnya memiliki sejumlah tuntutan baik sifatnya tuntutan internal maupun eksterna. Kepribadian, perilaku dan putusan yang diambilnya merupakan hal yang akan diteladani oleh orang yang dipimpinnya. Pendidikan Islam hadir sebagai 
204 Radif Khotamir Rusli \& Hasbi Indra

Konsep Manusia dalam Epistemologi Kepemimpinan

solusi alternatif yang mampu menjawab problematika kepemimpinan yang sejauh ini tergerus oleh fenomena politik dan ekonomi global yang kemudian juga telah membawa perubahan. Simpulan dari tulisan ini yakni manusia sebagai sosok pemimpin atau calon pemimpin hendaknya mampu memahami model kepemimpinan seperti apa yang hendak dijalankannya serta memiliki kecerdasan adversitas tinggi sebagai modal dirinya dalam memimpin.

\begin{abstract}
An Epistemology Of Leadership in Human Concept
Abstract: Being a function of human existence on this earth, even though biologically, human instincts are the leaders of creatures that are far different from animals that reproduce like mammals that contain, give birth, and breastfeed. However, in a group of certain species such as apes for example, has a leader or leader that is obeyed by the group. A crowd of ants or bees will always have an obedient objection to the queen to maintain the survival of the colony. It is no different from humans, of course since Adam was created as the first human, Allah SWT has equipped humans with a certain capacity as a system for human survival so that humans are maintained and sustainable even though there have been various tragedies in history, when compared to prehistoric times, dinosaurs have become extinct. swallowed up by the times. This study aims to describe the concept of leader and leadership along with the theory, function and factors that highlight the epistemology of leadership, especially regarding Islamic religious education as a religion of nature. This paper uses a qualitative approach with a documentation study method. The results of the study found that humans were gifted with the potential to develop themselves and become leaders in their environment. Being a leader has a village that is fine, both internally and externally. Personality, behavior and decisions he makes are things that will be emulated by those they lead. Islamic education is present as an alternative solution that can answer the problem of leadership which has so far been eroded by global political and economic phenomena which then also bring about change. This paper concludes that humans as leaders or prospective leaders who can understand what kind of leadership model they are running and have high adversity intelligence as their capital in leading.
\end{abstract}

\section{PENDAHULUAN}

Pada dasarnya sosok seorang
pemimpin tidak hanya tentang
intelektual, berwibawa, teknik
berkomunikasi, tampan, dan atribut
lain yang lekat dengan figure seorang

pemimpin. Sejatinya sorang pemimpin dapat dikatakan sebagai sosok yang memimpin para pengikutnya. Adanya pengikut tersebut pulalah yang kemudian menjadikan seseorang 
p-ISSN 2579-4876 | e-ISSN 2579-3470| 205

DOI: $10.30997 / j t m . v 4 i 2.3084$

berperan sebagai pemimpin yang memimpin.

Seorang invidu memperoleh pengakuan sebagai pemimpin bersumber dari penghormatan terhadap tanggungjawab yang diembannya. Hal tersebut kemudian mendorong timbulnya rasa percaya dari para pengikut kepada individu yang meimpinnya. Rasa pencaya tersebut merupakan pilar utama bagi seorang pemimpin yang mendasari para pengikut untuk menuruti arahan, menghormati putusan serta meneladani tindakan pemimpinnya. Berkaitan dengan hal tersebut, Baswedan (Baswedan, 2013) menyatakan bahwa kepercayaan itu sendiri terbentuk dari faktor kompetensi, integritas dan kedekatan yang berkolaborasi sedemikian rupa hingga membentuk rasa percaya pengikut pada pemimpinnya. Hal ini merupakan faktor pembentuk ketiga aspek tersebut pun berkontribusi pada tingkat kepercayaan pengikut terhadap seorang pemimpin. Namun perlu disadari bahwa terdapat faktor yang dapat menurukan kepercayaan seorang pemimpin, yaitu self-interest (Van
Knippenberg, Barbara, and Daan Van Knippenberg, 2005). Seseorang yang menafikan self-interest itu hampir dikatakan mustahil, karena kegagalan dalam mengelola dan mengendalikan self-interest dengan mencampurkannya kepada kepentingan kolektif berpotensi menyebabkan pengikisan kepercayaan terhadap pemimpin. Hal ini karena pemimpin yang terpercaya selalu menomorsatukan kepentingan kolektifnya dan mampu mengendalikan self-interest (Gillinson, 2004). Prioritas pemimpin pada kepentingan kolektif dibanding selfineterest akan berdampak luar biasa pada para pengikutnya. Mendahulukan kepentingan kolektif berarti pemimpin memperhatikan dan memajukan kepentingan bersama demi kemajuan bersama. Oleh sebab itu, peluang untuk meraih tujuan bersama akan lebih terbuka lebar karena pengikut akan tergerak untuk mewujudkan hal tersebut.

Pemimpin dan pemimpi memiliki kombinasi huruf yang hampir serupa, pembedanya justru ada pada huruf terakhir dari kedua kata tersebut yakni huruf D dan N. Sejatinya pemimpin 
adalah para pemimpi (Yuwana, 2019).

Pemimpi yang dipercaya dan diikuti akan mimpi-mimpinya, pemimpi yang mampu merealisasikan impiannya dan menggerakan orang lain untuk mewujudkan impian tersebut. Oleh sebab itu wajar jika dikatakan bahwa seorang pemimpin bermain dengan yang dibiarkan imaginasimya itu terbang tinggi lalu merealisasikan caracara mewujudkan imajinasi tersebut dalam kehidupan nyata. Adapun bentuk realisasi tersebut yakni bekerja dengan sepernuh hati, secara cerdas dan keras menggerakkan seluruh potensi dirinya untuk meraih dan melampaui mimpinya. Berdasarkan hal tersebut dapat dilihat perbedaan seorang pemimpin dengan pemimpi yakni mewujudkan mimpi dan berusaha melampauinya.

Pada praktiknya seorang pemimpin selalu menjadi sorotan. Oleh sebab itu seorang pemimpin hendaknya menyadari sisi kemanusiawiannya yang pasti memiliki ketidaksempurnaan dalam dirinya. Berdasarkan hal tersebut pemimpin seyogianya menyadari bahwa ketidaksempurnaan yang ada pada dirinya akan pula disorot oleh banyak orang. Baik kelebihan maupun ketidak sempurnaan seorang pemimpin akan selalu disorot oleh banyak orang. Apapun yang pemimpin lakukan khususnya yang berkaitan dengan ketidaksempurnannya memunculkan beragam persepsi dan bahkan kritikan. Oleh sebab itu tidak keliru pernyataan yang mengungkapkan bahwa bila tidak ingin dikritik maka jangan sesekali mau jadi pemimpin.

Sebagaimana telah disinggung sebelumnya bahwa seorang pemimpin hendaknya mendahulukan kepentingan bersama dibanding kepentingan pribadi. Namun, kedudukan seorang pemimpin yang harus memprioritaskan cita-cita bersama dalam memenuhi menjalani peranannya. Kepribadian yang matang tersebut selain berimplikasi pada pemenuhan peranan juga mendorong pemimpin memiliki kematangan jiwa dan ketulusan yang dilandari oleh rasa tanggungjawab yang tinggi. Karena itu ketika menerima pujian dirinya tidak akan terbang begitupun ketika dicaci dirinya tidak akan tumbang. (Baswedan, 2013)

Pemimpin yang diidamkan adalah mereka yang tidak mengejar 
p-ISSN 2579-4876 | e-ISSN 2579-3470 207

DOI: $10.30997 / j t m . v 4 i 2.3084$

penghormatan, tapi ia menjaga kehormatan. Penghormatan itu memang mudah untuk dipanggungkan dan gampang dibeli karenanya akan didapat dengan mudah. Namun bagi seorang pemimpin yang menjaga kehormatan tidak akan memperjualbelikan sebuah kehormatan dan malah memperoleh kehormatan. Ada banyak contoh pemimpin di republik ini yang keteladanannya menjadi rujukan, gagasannya dikuti, langkahnya menginspirasi. Masalahnya kemudian, adalah juga banyak dari mereka yang tidak berada di tampuk kekuasaan dan otoritas. Karena yang berada di panggung-panggung penting yang sering ditemui adalah orangtanpa kepemimpinan.

\section{METODE}

Penelitian ini menggunakan pendekatan kualitatif dengan teknik studi dokumen. Hal ini sesuai dengan tujuan penelitian ini untuk penelitian sifat manusia dalam epistomologi kepemimpinan. Dokumen yang menjadi objek utama penelitian adalah Quran. Quran terpilih sebagai sumber utama dengan pertimbangan bahwa al-
Quran adalah kitab suci yang berisi kumpulan wahyu dari Allah sebagai jalan hidup bagi manusia dan Kitab Suci yang berfungsi sebagai pengingat kebenaran, bukan hanya di sini dan sekarang, tapi sampai akhir hari.

Mengingat Kitab Suci Quran dalam bahasa Arab, untuk memahaminya diperlukan kemampuan Bahasa Arab. Namun, untuk memahami Quran tidak sesederhana itu. Yusuf al-Qardhawi (2000: 285) memperingatkan bahwa, Quran adalah kitab yang jelas, mudah diingat dan dipahami; Quran diturunkan dalam Bahasa Arab, dimana mengandung banyak kemungkinan arti baik secara sharih (jelas, terang) kinayah (perumpamaan), alam, angka, berbicara, khas (khusus) dan 'aam (umum), mutlak (absolut) dan muqayyad (terbatas), manthuq (eksplisit), dan mafhum (implisit). Ada juga yang perlu dipahami sebagai isyarat karena bersifat isti'arah (metafora). Kemampuan manusia untuk memahami Al-Quran berbeda. Ada orang yang hanya mampu memahami makna zahir tekstual dan ada juga orang yang mampu memahami secara ekstensif (mendalam). Bahkan ada pula orang 
208 Radif Khotamir Rusli \& Hasbi Indra

Konsep Manusia dalam Epistemologi Kepemimpinan

yang tidak mampu memahami arti sebenarnya, dan beberapa ayat dari Quran diturunkan berkenaan dengan alasan dan peristiwa. Jika dipahami dengan baik, itu akan meningkatkan pemahaman, dan itu akan membantu untuk memahami Al-Qur'an dengan benar. Oleh karena itu, untuk mendapatkan pemahaman yang benar dan mendalam, perlu dirujuk melalui buku-buku tafsir Quran (Yusuf Qardhawi (2000:. 283) yang disusun oleh para ahli metode Interpretasi yang digunakan adalah metode Maudhu'I atau tematik.

Metode Maudhu'i (tematik) yang dirumuskan oleh Nashruddin Baidan (2000: 151), ini membahas ayat-ayat AlQuran sesuai dengan tema atau judul yang telah ditetapkan. Semua ayat-ayat yang berkaitan disusun dan kemudian dipelajari secara mendalam dari berbagai aspek yang terkait makna, kosakata, dan sumber-sumber aslinya. Terdapat dua bentuk penafsiran maudhu'i, yaitu:

1. Menyajikan pesan dari Al-Qur'an pada spesifik masalah diringkas dalam satu surah saja, dan
2. menyajikan pesan-pesan Al-Quran tentang isu-isu tertentu yang terkandung dalam berbagai surah. (Shihab, 1996)

Selain dari rujukan text murni di atas, penulis juga merujuk kepada teoriteori umum yang digunakan dalam disiplin ilmu Manajemen, dengan demikian terjadi keseimbangan antara pemahaman umum yang bersumber dari ilmu modern dan juga secara filosofis dikupas dengan menerapkan nilai-nilai ketauhidan melalui al-Quran.

\section{HASIL \& PEMBAHASAN}

Pemimpin adalah mereka yang terdepan dan menentukan arah jalan. Pemimpin memiliki visi dan misi yang jelas, guna mencapainya pemimpin akan menginspirasi; merekalah yang kemudian akan menerima semua kritik, serangan, bahkan cemoohan. Tetapi mereka juga akan bertanggung jawab ketika berhasil atau sebaliknya bertanggung jawab pula ketika terjadi kegagalan. (Dahlan, t.t.)

Pekerjaan seorang pemimpin adalah merumuskan sebuah visi, yang merupakan arah tujuan, mereka digerakan oleh visi dan misi, bukan oleh 
p-ISSN 2579-4876 | e-ISSN 2579-3470

209

DOI: $10.30997 /$ jtm.v4i2.3084

semata-mata mengikuti peraturan. Oleh karena itu, kecerdasan merumuskan visi yang orisinal dan realistik merupakan bagian dari performa kepemimpinan seseorang.

(Kartakusumah, 2006)

Seseorang yang memimpin perubahan mungkin harus mengubah kinerja perubahan dengan maksud untuk memberikan dukungan agar dapat lebih efektif. Pada praktiknya seorang pemimpin harus mampu berperan sebagai seorang mentor yang mampu mendorong perubahan tersebut ada dalam dirinya sendiri. Perubahan yang terdorong dari diri sendiri merupakan modal dasar untuk melakukan perubahan di lingkungan sekitarnya. Oleh sebab itu, pemimpin yang mampu merubah dirinya maka akan mampu melakukan perubahan pada kinerja dalam organisasi yang dipimpinnya. Dalam proses pembelajaran, diperlukan sebuah apreasiasi; sehingga pemimpin turut bertanggung jawab menyiapkan generasi calon pemimpin untuk dapat menciptakan pemimpin yang akan datang, misalnya melalui proses pelatihan mentor. Mentor berasal dari
Bahasa Yunani, yaitu nama orang yang diamanahkan oleh Odysseus (Ulysses) supaya menjaga anak lelakinya bernama Telemachus yang berumur 10 tahun. Mentor adalah orang penting bagi seseorang untuk sukses dalam berbagai bidang yang diikuti. Mentor akan membantu orang dalam bidang yang baru diikuti untuk mengatasi tantangan yang dihadapi. Seorang mentor menyerupai petunjuk isyarat dari yang memberi bimbingan kepada anggotanya (mentee). Mentor akan memberikan ajaran yang cukup dalam hal-hal secara spesifik untuk membentuk kualitas kepribadian mentee. (Abdullah, Salhah, and Ainon Mohd., 2005)

Pemimpin adalah seseorang yang memiliki berbagai karakter, diantaranya adalah sebagai berikut:

a. Keterpanggilan \& kemanusiaan (Widayat, 2014)

b. Kepelayanan, ketulusan, kesantunan (Mahessa, Nurul Fathia, and N. R. H. Frieda, 2017)

c. Perjuangan, penderitaan, pengorbanan, kepahlawanan (Aditya, Purwa, I. Made Pageh, and Ketut Sedana Arta, 2017) 
210 Radif Khotamir Rusli \& Hasbi Indra

Konsep Manusia dalam Epistemologi Kepemimpinan

d. Tanggungjawab (Faturahman, 2018)

e. Kepribadian, keteladanan (Marwah, 2018)

f. Inisiatif, inovasi, resiko (Syahrul, 2015)

g. Kredibilitas, integritas, amanah, trust (Aryani, L., Marettih, A. K. E., Cucuani, H., Susanti, R., \& Lestari, Y. I., 2013)

h. Kemampuan kapasitas, kompetensi (Aryani, L., Marettih, A. K. E., Cucuani, H., Susanti, R., \& Lestari, Y. I., 2013)

i. Pengalaman, wawasan (Amin, Surahman, and Ferry M. Siregar, 2015)

j. Intelektualitas, emosionalitas, spiritualitas (Rodliyah, 2019)

k. Totalitas, konflik kepentingan (Fitriyah, Nurul, and Agus Suliyadi, 2018)

1. Efektivitas, skala prioritas (Nurhayati, 2014)

m. Kharisma, Mitos, objektivitas, Rasionalitas (Yuliana, Baiturrohma, and Isro Ani Widayati, 2018)

n. Popularitas, Otentisitas, elektabilitas (Ni'mah, 2015)

o. Motivasi, pemberdayaan, kerja tim (Pratasik, 2013) p. Pilihan, level, pengaruh (Othman, Norasmah, Siti Junaidah M. Mujir, and Mohammed Sani Ibrahim, 2012)

q. Empati, solidaritas, kebersamaan, modal sosial (Sumarni, Sri, Achmad Dardiri, and Darmiyati Zuchdi, 2015)

r. Mindset, mental, kultur (Rohmat, 2016)

s. Komunikasi, propaganda, lobi, negosiasi (Ardianto, A., Prisanto, G. F., Irwansyah, I., Ernungtyas, N. F., \& Hidayanto, S., 2020)

t. Momentum, upacara perubahan (Mahmudin, Shafwan, and Trisni Andayani, 2017)

u. Daya saing (Aminah, 2018)

v. Dedikasi, loyalitas (Budiono, 2012)

w. Patriotisme, kenegarawanan (Sridiyatmiko, 2019)

Kepemimpinan bukanlah suatu kecakapan yang mudah dipelajari, tetapi menjadi pilihan terbaik untuk melancarkan mekanisme hubungan industri. Kepemimpinan merupakan fondasi bagi suksesnya sebuah bisnis atau organisasi. Kaum militer sudah lama mendapatkan pelajaran ini Sebagaimana dikatakan dengan ringkas oleh Euripides, penyair Yunani yang 
meningga tahun 406 SM. "Sepuluh serdadu baik yang dipimpin dengan bijak akan mengalahkan seratus serdadu musuh tanpa pemimpin". Sukses dalam peperangan atau pertempuran cenderung berkaitan dengan kepemimpinan yang hebat pada semua tingkatan. (Adair, Cara Menumbuhkan Pemimpin, 2007)

Kepemimpinan terdapat dalam tiga garis besar tingkatan, dulu saya sebut strategis, operasional, dan kelompok; istilah ini kini mulai sering dipakai. Kekeliruan pemikiran yang biasa terjadi adalah menganggap sebuah organisasi hanya butuh seorang pemimpin strategis yang hebat dalam memimpin. Ternyata, rahasia sukses dalam bisnis adalah kepemimpinan yang sangat hebat dalam ketiga tingkatan itu. Perusahaan-perusahaan mungkin bisa merekrut pemimpin bisnis strategis yang baru dengan menggaji mereka sangat tinggi, seperti klub- klub sepak bola kelas dunia yang mengganti manajer mereka.

Tugas seorang pemimpin bukanlah semata-mata mengerjakan satu hal saja, tetapi justru harus dapat membuat orang lain menyelesaikan pekerjaan yang sulit dengan baik, cepat, dan tanpa paksaan, bahkan dengan rasa senang karena ia dapat menikmati pekerjaan itu. Sejumlah aspek lain dalam berbagai situasi memerlukan kepemimpinan keberanian dalam kekalahan, inspirasi dalam apatisme, dan kejernihan pikiran dalam kekalutan. Namun, hal mendasar yang diperlukan adalah mereka yang dipimpin hendaknya memahami tugas mereka, memercayai pemimpin mereka, dan mengetahui apa yang harus dilakukan. Karena itu, kepemimpinan secara luas bukanlah sesuatu yang sudah dipahami kebanyakan orang. Kepemimpinan adalah kecakapan yang dapat dipelajari. Adair (2007) telah menemukan cara menunjukkan kepada para kadet apa yang diperlukan seseorang dalam memberi perintah kepada suatu kelompok, baik sebagai letman yang mengepalai sebuah kompi maupun sebagai supervisor dalam lini produksi Dengan tegas tapi santai, ia mengesampingkan apa yang dinamakan "pendekatan kualitas" terhadap kepemimpinan. Pendekatan ini memperkenalkan karakteristik 
212 Radif Khotamir Rusli \& Hasbi Indra

Konsep Manusia dalam Epistemologi Kepemimpinan

komandan-komandan yang hebat dan

kemudian berharap kadet- kadet Anda

akan mengikuti contoh mereka.

Pendekatan ini sangat tidak

memuaskan sebagaimana diperlihatkan

daftar kualitas kepemimpinan yang

disusun berbagai Lembaga. (Adair,

2007)

Bila membaca hikayat tentang pemimpinan-pemimpinan di jaman para Nabi dan Rasul, baik pemimpin suku, kafilah, bangsa, wilayah atau negara yang bermartabat betapa jabatan sebagai pemimpin adalah jabatan yang paling dihindari sebab dengan ditunjuknya menjadi pemimpin maka orang-orang yang berkualitas itu merasa berkurang kesempatannya untuk mendapatkan' "surga", sebab pemimpinlah yang paling berat bebannya dan pemimpinlah yang terakhir "kenyang" setelah warganya tidak ada yang kelaparan. Pemimpinlah yang terakhir sejahtera setelah warganya sejahtera. Oleh karena di dalam masyarakat suatu negara pastilah ada yang miskin maka ketika seseorang ditunjuk sebagai pemimpin maka seluruh hartanya yang ada sebelum ia menjadi pemimpin habis didermakan dan dibagikan untuk negara dalam rangka menyantuni masyarakat miskin dan terlantar setidaknya itulah yang ditunjukkan oleh para pemimpin-pemimpin yang hidup dijaman para pemimpin sejati jaman dahulu kala.

Selanjutnya hingga dewasa ini kita tidak pernah dan (semoga akan pernah) melihat lagi orang-orang yang menganggap dirinya cakap dan berharta menolak ditunjuk jadi pemimpin. Jangankan menolak, bahkan rebutan untuk menjabat, dari tataran yang sangat rendah (ketua RT) sampai dengan tertinggi (Presiden). Padahal jelas jabatan pemimpin adalah pekerjaan amanah yang sangat-sangat berat beban dan tanggung jawabnya.

Memang harus diakui bahwa setiap manusia diciptakan (dilahirkan) untuk menjadi pemimpin, akan tetapi dalam konteks yang universal yaitu menjadi pemimpin dirinya sendiri. Sedangkan untuk menjadi pemimpin keluarga, pemimpin suku, bangsa, agama, dan umat serta negara memiliki kreteria dan persyaratan tersendiri. Meskipun setiap orang punya bakat memimpin akan tetapi tidak semua orang dapat 
p-ISSN 2579-4876 | e-ISSN 2579-3470

213

DOI: $10.30997 /$ jtm.v4i2.3084

memimpin. Memimpin haruslah didukung selain bakat juga ilmu dan pengetahuan. Pengetahuan bisa dari turunan, mendengar dan membaca serta pengalaman sendiri. Sedangkan ilmu memimpin harus dipelajari dari pengalaman pemimpin berdasarkan aturan dan etika tertentu.

Pemimpin agama tidak hanya harus menguasai bidang keagamaan, juga dituntut untuk menguasai ilmu agama serta pengetahuan mengenai umatnya. Namun perlu difahami bahwa pemimpim agama tidak berarti bahwa dirinya harus lebih pintar seluruh pemeluh agama, tetapi dituntut untuk lebih memahami ilmu dan praktik agama dibanding dengan pemeluk agama tersebut. Hal ini karena pemimpin agama merupakan sosok yang dipatuhi dan dimintai penjelasan dan mengenai agama yang dianutnya. Pemimpin agama yang didasarkan hanya menguasai bahasa dan membaca kitab sucinya sementara tidak menguasai aspek ilmu lainnya yang berhubungan dengan agamanya bukanlah pemimpin agama, melainkan hanya ketua atau bos agama, atau pemuka agama, atau tokoh agama.
Pemimpin organisasi selain menguasai ilmu organisasi, harus mengetahui keadaan organisasinya secara mendalam dan menguasai orang-orang yang ada di dalamnya. Menguasai disini merujuk pada anggota organisasi yang patuh dan menghormati serta men-support kepemimpinan yang dijalankannya. Rasa hormat menjadi hal yang penting dan membedakan sosok yang dianggap sebagai seorang pemimpin dan seorang yang berperan sebagai manajer yang di patuhi namun kurang dihormati dalam organisasi tersebut. Pemimpin bangsa atau rakyat haruslah menguasai tentang bangsa dan tahu rakyatnya.

Tahu dan menguasai ilmu tentang pemerintahan dan kerakyatan. Harus tahu berapa banyak yang miskin sehingga ia harus lebih miskin. Harus tahu apakah ada yang kelaparan, sehingga ia baru bisa kenyang setelah tahu rakyatnya sudah tidak ada yang kelaparan. Seseorang yang berambisi menjadi pemimpin tetapi pada kenyataannya hanya berorientasi pada peningkatan penghasilan, memperoleh fasilitas mewah dan memikirkan sekejahteraan pribadi sesungguhnya 
214 Radif Khotamir Rusli \& Hasbi Indra

Konsep Manusia dalam Epistemologi Kepemimpinan

tidak memiliki jiwa seorang pemimpin yang dapat mempertanggungjawabkan amanah yang diembannya sebagai pemimpin.

Seorang pemimpin tahu dengan benar bagaimana semestinya ia bersikap didepan khalayak. Dirinya akan menunjukan sosok pribadi yang dapat menjadi role model bagi orangorang yang dipimpinnya. Karena itu seorang pemimpim akan bersikap sahaja dengan tidak mengedepankan ego pribadi yang tidak perlu untuk ditunjukan pada khalayak. Dilandasi oleh rasa tanggungjawab terhadap yang dipimpinnya, seorang pemimpin tidak akan mudah untuk menuduh dan menyalahkan, tetapi terlebih dahulu akan menganalisis guna memperoleh pemahaman yang benar untuk memutuskan sebuah perkara berdasarkan hukum yang berlaku dan kebenaran sejati. Pemimpin akan mendorong lingkungan sekitarnya untuk mencapai tujuan bersama demi terwujudnya kesejahteraan bersama.

Sosok pemimpin sesungguhnya tidak akan permah memanfaatkan kekuasaannya untuk mengeruk keuntungan pribadi. Namun pada praktiknya penggunaan kekuasaan tetap ada untuk hal-hal yang sifatnya mendesak demi kebaikan seperti penjamin kebenaran, penjamin kejujuran dan kemaslahatan. Berdasarkan hal tersebut, pemimpin dapat membebaskan tuduhan terhadap orang yang diduga bersalah bila ada bukti yang mematahkan tuduhan di hadapan pengadilan selama dilandasi oleh hukum yang berlaku. Karena itu seorang pemimpin dapat membatalkan hukum atas manusia yang dipimpinnya tanpa memandang status sosialnya dan tetap berlandaskan pada asas hukum yang adil.

Pada dasarnya menjadi seorang pemimpin bukanlah hal yang mudah. Hal ini karena seorang pemimpin akan menanggung resiko hidup yang besar. Sehingga aneh kiranya bila kita menelaah fenomena saat ini dimana banyak orang berebut kekuasaan berambisi menjadi seorang pemimpin. Kondisi tersebut bertentangan dengan jiwa seorang pemimpin sesungguhnya yang hanya akan hadir bila peranannya dibutuhkan oleh khalayak. Karena itu dalam kondisi dimana keadaan 
kondusif dan aman maka seorang dengan jiwa pemimpin justru akan mengundurkan diri dari kedudukannya sebagai pemimpin. Pada kondisi yang kondusif sosok yang akan berkedudukan sebagai pemimpin seyogianya harus ditunjuk oleh pihak yang berwenang dan memiliki ilmu pengetahuan yang mumpuni dalam hal tersebut salah satunya seperti Ulama.

Berkaitan dengan paparan tersebut diatas, kedudukan sebagai pemimpin sebaiknya tidak harus melalui pemilu. Adapun pemilu sesungguhnya lebih tepat digunakan untuk memilih bos atau manager atau administratur. Pemimpin yang ditunjuk oleh pihak berwenang dan memiliki ilmu yang mumpuni dalam kepemimpinan atau dapat pula pemimpin yang mengajukan dirinya sendiri dalam kondisi kritis tidak akan keberatan bila dirinya harus melepaskan jabatannya sebagai pemimpin bila kondisi telah kondusif kembali. Hal ini akan berbeda dengan manager atau bos yang dipilih melalui pemilu maka akan muncul tanpa menghiraukan kondisi yang terjadi disekitarnya. Hal tersebut mendorong timbulnya persaingan memperebutkan kedudukan sebagai pemimpin karena menginginkan kekuasaan, dihormati, memperkaya diri dan hal-hal yang bersifat keuntungan pribadi. Seorang pemimpin yang sesungguhnya lebih berorientasi sebagai manager atau bos hanya akan berhasil pada skala kecil dan jangka pendek.

Menghadapi kondisi kritis dan dituntut pertanggungjawaban maka seorang pemimpin sejati tanpa gentar akan menghadapi permasalahan paling depan, tetapi dalam kondisi yang kondusif dan keberhasilan seorang pemimpin sejati justru menghindar untuk memperoleh pujian berlebih. Hal tersebut berbeda dengan sosok seorang manager atau bos yang cenderung melemparkan kesalahan pada bawahannya dan menuntut pertanggungjawaban dari bawahan atas permasalahan yang tengah dihadapi. Adapun dalam keberhasilan maka dirinya berada paling depan untuk memperoleh sanjungan.

Berdasarkan paparan diatas jelas bahwa sosok seorang pemimpin sejatinya menghayati dengan sungguhsungguh konsep “Ditunjuk Langsung 
216 Radif Khotamir Rusli \& Hasbi Indra

Konsep Manusia dalam Epistemologi Kepemimpinan

oleh Tuhan" yang merujuk pada Nabi dan Rasul-Nya sebagai pemimpin sejati para umat-Nya. Selain itu sosok pemimpin sejati pun memahami betul istilah "Wakil Tuhan di Dunia" yang bermakna seseorang yang ditunjuk oleh pihak yang berwenang dan berilmu dibidang kepemimpinan misalnya Ulama (apapun agamanya) untuk diamanahi sebagai pemimpin. Pihak berwenang dan berilmu sebagai perwakilan rakyat bila tidak tidak amanah dalam melaksanakan tanggungjawabnya menunjuk pemimpin yang dapat menimpin maka berpotensi menempatkan seorang yang berlaku sebagai seorang bos, administrator atau manager saja bukan sosok pemimpin sejati. Mengapa demikian? Hal ini karena hanyalah orang amanah yang dalam bertanggungjawab sepenuhnya, tulus, bekerja keras, cerdas, jujur dan pintar yang dapat memilih dan menunjuk orang yang layak menjadi pemimpin. Perwakilan rakyat yang tidak amanah, tidak jujur, tidak cerdas cenderung memiliki seorang pemimpin berdasarkan pada otaknya saja atau hatinya saja sehingga memunculkan bias. Mengapa? Untuk menjadi pemimpin yang banyak diperebutkan dan menjadi dambaan kebanyakan orang- orang maka pelajaran bagaimana menjadi pemimpin paling banyak diminati. Padahal bila ditelaah kembali pelajaran menjadi seorang pemimpin pada dasarnya hanya mengajarkan bagaimana sosok pemimpin merepresentasikan dirinya dengan baik didepan umum terlepas dari kepribadian orang tersebut baik atau tidak. Meskipun apa yang ditampilkan tidak sesuai dengan faktanya, menunjukan yang terbaik didepan umum menjadi sebuah kewajiban yang diajarkan dalam pelajaran menjadi seorang pemimpin. Sebuah teori kepemimpinan $\mathrm{X}$ menyatakan bahwa untuk menjadi seorang pemimpin tidak harus menjadi orang yang baik, tetapi berusaha untuk tampil dengan baik. Oleh karena itu, kiranya sangat mungkin sekali ada seorang pemimpin yang sebenarnya background-nya adalah seorang penjahat bila dirinya mampu tampil dengan baik didepan umum dan tentunya memiliki fasilitas yang mendukungnya menduduki jabatan sebagai pemimpin. 
Disisi lain orang yang layak menjadi pemimpin sebagai "Wakil Tuhan Di Dunia" justru tidak dapat menduduki posisi sebagai pemimpin manakala dirinya tidak mampu tampil baik didepan umum karena rumor negatif yang disebarkan oleh orang-orang yang tidak bertanggungjawab.

Bila ada sebagian pakar atau bahkan awam sekalipun yang menyatakan bahwa kepemimpinan merupakan hal yang bersifat turun temurun, dalam artian bila moyangnya dahulu menduduki kabatan sebagai pemimpinan maka keturunannya berpotensi besar menjadi pemimpin, dan sebaliknya bila tidak ada garis keturunan pemimpin maka sangat tidak mungkin dapat menduduki posisi sebagai pemimpin kemungkinan didasari oleh teori kepemimpinan X. Implementasi dari penganut stigma tersebut dimasyarakat yakni banyak yang menyakini bahwa untuk menduduki jabatan seperti lurah haruslah memiliki garis keturunannya apakah moyangnya pernah menjadi lurah atau tidak. Begitupun untuk menjadi seorang menteri, jenderal, gubernur, adakah garis keturunan yang pernah menjabat kedudukan tersebut sebelumnya. Sesungguhnya bila ditelaah kembali, stigma tersebut muncul berdasarkan pemahaman bahwa garis keturunan dan bakat memiliki pengaruh terhadap posisi seseorang dimasa depan. Sebagai contoh, seseorang dengan garis keturunan sebagai petani atau pemulung maka kecil kemungkinan generasi penerusnya saat ini menduduki kursi pemimpin an turunannya sekaran bisa menjadi pemimpin karena tidak memiliki dasar sebagai pemimpin. Bila kita telaah kembali profil para pemimpi Indonesia tidak semuanya terlahir dari orang tua yang menduduki jabatan sebagai pemimpin. Pak Soekarno dan Pak Soeharto tidak terlahir dari Ayah Ibu yang pernah menjabat sebagai pemimpin. Namun Ibu Megawati dan Pak Gus Dur telahir dari background pemimpin. Adapun Pak Habibie sebagaimana Pak Soekarno dan Soeharto tidak terlahir dalam keluarga pemimpin. Sedangkan Pak Susilo (SBY) pada dasarnya tidak terlahir dari keluarga pemimpin namun mertua beliau adalah seorang pemimpin. Dari 
218 Radif Khotamir Rusli \& Hasbi Indra

Konsep Manusia dalam Epistemologi Kepemimpinan

para pemimpin tersebut dapat kita kaji

apakah sosoknya sebagai pemimpin

sejati atau hanya berperan sebagai bos, manager dan administrator negara saja.

Pak Soekarno sebagai Presiden RI pertama dipilih bukan saja ditunjuk tetapi juga oleh rakyat Indonesia, karena itu wajar bila kedudukannya sebagai pemimpin dikembalikan lagi kepada rakyat. Pak Soeharto sebagai Presiden RI kedua pada dasarnya dipilih oleh rakyat melalui perwakilan rakyat "Wakil Tuhan" dan kemudian mengembalikan lagi tampuk kepemimpinannya kepada rakyat meskipun melalui paksaan.

\section{Kepemimpinan}

Pengertian kepemimpinan (leadership) dapat ditampilkan sebagai berikut:

1. Suatu aktivitas mempengaruhi orang, agar dapat bekerjasama untuk menggapai beberapa tujuan diinginkan. (Tead, 1935)

2. Seni membujuk anggota untuk menyelesaikan semua pekerjaan secara bersemangat dan meyakinkan. (Koontz \& O' Donnelle, 1976)
3. Proses mempengaruhi kegiatan baik secara individual ataupun sosial dalam rangka mencapai suatu tujuan dalam situasi tertentu. (Hersey \& Blanchard, 1982)

4. Proses mempengaruhi orang lain untuk memahami dan menyetujui apa yang diperintahkan dan melaksanakan pekerjaan sesuai dengan arahan serta bagaimana pekerjaan tersebut dapat berjalan efektif guna mencapai tujuan bersama. (Yukl, Gary, 2005)

5. Memimpin adalah mempengaruhi, dimana suatu kehidupan yang mempengaruhi kehidupan lain.

(Maxwell, 1967)

Berdasarkan paparan diatas dapat kemukakan definisi kepemimpinan (leadership) yang lebih mudah difahami yaitu sebagai berikut:

Kepemimpinan mengarah pada sebuah proses pengaruh sosial dalam; hubungan interpersonal, menerapkan sebuah keputusan, berorientasi pada pencapaian tujuan bersama,

Kepemimpinan juga dapat dimkanai sebagai sebuah proses untuk mempengaruhi orang lain agar dapat 
p-ISSN 2579-4876 | e-ISSN 2579-3470|| 219

DOI: $10.30997 /$ jtm.v4i2.3084

melaksanakan perilaku yang diharapkankan guna mencapai tujuan.

Berdasarkan definisi tersebut dapat diketahui bahwa ada tiga komponen penting dalam sebuah kepemimpinan yaitu:

a. Pengaruh; Kepemimpinan adalah pengaruh yang mempengaruhi; dimana kepemimpinan terjadi karena adanya proses pengaruh mempengaruhi ke arah yang diinginkan.

b. Legitimasi; merupakan pengakuan terhadap kedudukan seorang pemimpin, dan legitimasi pun pada dasarnya menunjukan posisi formal yang memiliki kekuasaan (power) di dalam sebuah organisasi. Pemimpin berlegitimasi institusional atau personal pada dasarnya dapat dapat mempengaruhi, mengarhkan maupun memerintah para pengikutnya, sehingga mereka rela dipimpin oleh orang yang memiliki legitimasi itu.

c. Tujuan; Dimana pemimpin berurusan dengan tujuan. tujuan yaitu; (1) tujuan individu, (2) tujuan kelompok, dan (3) tujuan organisasi. Salah satu keberhasilan seorang pemimpin dapat ditelaah dari kepuasaan para pengikutnya dalam melaksanakan perintah oemimpin tersebut. Adapun kepuasan tersebut dapat muncul manakala pemimpin mampu menciptakan keseimbangan antara tujuan hendak dicapai dengan keinginan dari pra pengikutnya.

Seseorang berkedudukan sebagai pemimpin sesungguhnya dapat melalui berbagai jalur. Adapun jalur kepemimpinan antara lain sebagai berikut:

a. Tradisional (warisan); artinya sesorang menjadi pemimpin karena keturunan, misalnya putra mahkota pada suatu kerajaan.

b. Kepribadian; artinya sesorang yang berkepribadian tertentu menjadi pemimpin, baik secara fisik maupun kepribadian etikanya.

c. Pengangkatan atasan; artinya sesorang menduduki jabatan sebagai pemimpin atas dasar pengangkatan oleh atasannya dalam struktural organisasi dimana dirinya berada. 
d. Kepercayaan kelompok; artinya sesorang menjadi pemimpin karena ditunjuk oleh para anggota kelompok yang menaruh rasa percaya pada dirinya bahwa ia akan mampu memimpin kelompok tersebut.

e. Situsional; artinya menjadi pemimpin karena ada peluang dan suatu kesempatan, sehingga lingkungan dan orang-orang sekitar dapat mendukungannya.

f. Pemilihan; artinya menjadi pemimpin dikarenakan hasil pemilihan dari para anggota.

Hal ini didasarkan pada konsep acceptance theory; "Anda menjadi pemimpin dan kami akan menaati instruksi dan pengarahan anda." Pemimpin hasil dari sebuah pemilihan biasanya akan lebih baik, karena pemilih dalam memilih pemimpin berdasarkan pada berbagai pertimbangan yaitu sebagai berikut:

a. Adanya keinginan, keseriusan, dan kemauan calon untuk menjadi pemimpin;

b. Kreativitas dan keefektifan calon dalam berkomunikasi; c. Kecakapan dan kecerdasan calon membuat konsep uraian yang logis dan dapat diterima oleh anggota;

d. Integritas, prilaku, kejujuran dan moral calon yang diterima oleh anggota;

e. General and special knowledge, pendidikan dan pengalaman calon.

f. Kemampuan hubungan- hubungan baik internal maupun eksternal organisasi dari calon.

Pencalonan dan pemilihan harus dilakukan secara obyektif, tidak ada rekayasa sehingga berjalan secara langsung, umum, bebas, rahasia (LUBER). Hal ini penting dan sangat menentukan bahwa pemimpin hasil pemilihan itu benar dan terbaik atau efektif.

Faktor-faktor kepemimpinan meliputi hal-hal berikut:

a. Leader atau head; adalah orang yang memimpin

b. Followers; adalah pengikut atau orang-orang yang dipimpin

c. Power; adalah kemampuan yang luar biasa untuk mempengaruhi pengikutnya. 
p-ISSN 2579-4876 | e-ISSN 2579-3470

221

DOI: $10.30997 /$ jtm.v4i2.3084

d. Influence; berupa adalah tindakan mempengaruhi yang merupakan perilaku penyebab perubahan sikap pengikutinya.

e. Value; yaitu nilai keyakinan dasar yang dapat mempengaruhi perilaku pengikut dalam kelompok.

f. Objective; atau tujuan yang merupakan sasaran yang ingin dicapai secara bersama-sama.

Adapun fungsi-fungsi Kepemimpinan adalah agar kelompok atau organisasi berjalan dengan efektif, maka seorang pemimpin harus melaksanakan dua fungsi utama yaitu sebagai berikut:

a. Decision making (pengambilan keputusan)

b. Directing (pengarahan)

c. Delegation (pendelegasian)

d. Empowerment (pemberdayaan)

e. Facilitating (Fasilitasi)

f. Controlling (Pengendalian)

Selain dari itu, fungsi-fungsi kepemimpinan dalam organisasi antara lain:

a. Task related, yaitu fungsi yang berhubungan dengan tugas atau pemecahan masalah. Hal ini Mencakup penetapan struktur tugas, pemberian saran

penyelesaian, informasi, dan pendapat.

b. Group maintenance, yaitu mengarah pada fungsi yang berkaitan dengan pemeliharaan kelompok atau sosial, fungsi tersebut meliputi hal-hal yang dapat mengarahkan dan membantu organisasi dapat berjalan dengan baik, kesepakatan dengan organisasi lain, serta mediator dalam menengahi perbedaan pendapat yang timbul dalam organisasi.

Malayu Hasibuan mengemukakan fungsi-fungsi kepemimpinan antara lain:

a. Pengambilan keputusan dalam merealisasi keputusan itu.

b. Pendelegasian kewenangan dan pembagian kerja.

c. Meningkatkan kinerja dan capaian bagi semua unsur manajemen,

d. Memotivisi, supaya seluruh elemen organisasi dapat bekerja secara efektif.

e. Mengembangkan imajinasi, kreativitas, dan loyalitas.

f. Pemrakarsa, penggiat, dan pengendali rencana. 
222 Radif Khotamir Rusli \& Hasbi Indra

Konsep Manusia dalam Epistemologi Kepemimpinan

g. Mengkoordinasi dan mengintegrasi seluruh kegiatan organisasi.

h. Penilaian terhadap pencapaian maupun teguran serta penghargaan melalui pendidikan dan pelatihan sebagai pengembangan sumber daya manusia.

i. Melaksanakan tindakan pengawasan dan tindakan perbaikan yang dianggap perlu.

j. Memelihara semua aktivitas yang berada di bawah kewenangannya.

k. Mempertanggungjawabkan tindakan serta putusan yang diambilnya dalam menjalankan kewenangan serta tanggungjawab kepada stakeholders.

1. Membina dan berusaha mempertahankan keberlangsungan organisasi yang dipimpinnya.

m. Memberikan ganti rugi, ketenangan, dan keselamatan bagi bawahan yang dipimpinnya.

n. Meningkatkan produktivitas dan alokasi sumber

o. Meningkatkan tingkat kepuasan kerja karyawan.

p. Menciptakan pembaharuan, perubahan, dan reformasi. (Hasibuan, 2016)
Lebih lanjut, pemimpin dalam kelompok atau organisasi berperan dan berfungsi sebagai:

a. Promotor

b. Motivator

c. Delegator

d. Komunikator

e. Mediator

f. Integrator

Setidaknya dalam teori kepemimpinan diknela enam tipologi kepemimpinan yang diakui hingga saat ini, yaitu:

a. Tipe Otoriter; adalah jenis pemimpin yang memutuskan secara sepihak berbagai keputusan bagi para pengikutnya. Pada tipe ini tidak mengenai asas demokrasi dalam menentukan putusan bagi kepentingan bersama.

b. Tipe Demokratis; tipe demokratis merupakan jenis pemimpin yang mengambil keputusan dilandasi pula oleh pertimbangan dari para bawahannya. Tipe pemimpin demokratis memberikan bawahannya kesempatan untuk menyampaikan aspirasi demi kebaikan bersama. 
p-ISSN 2579-4876 | e-ISSN 2579-3470| 223

DOI: $10.30997 /$ jtm.v4i2.3084

c. Tipe Liberal; adalah jenis pemimpin yang pada banyak penetapan putusan cenderung menyerahkan pada pihak lain sehingga dirinya dengan bebas memberi kewenangan memutuskan pada bawahan.

d. Tipe Populis; merupakan tipe pemimpin yang capak membangun solidaritas pada para pengikutnya dalam menjalankan organisasi.

e. Tipe Kharismatik; pemimpin dengan tipe kharismatik merupakan sosok seorang pemimpin yang berwibawa, memiliki kepribadian yang istimewa sehingga dirinya dihormati dan dikagumi oleh para pengikutnya. Penghormatan tersebut menjadi dasar bagi loyalitas dan kepatuhan pengikut kepada pemimpin tersebut.

f. Tipe Kooperatif; pemimpin dengan tipe kooperatif merupakan sosok pemimpin yang memiliki dan mejalankan kepemimpinannya berlandaskan pada jiwa Pancasila. Oleh sebab itu, pemimpin tipe kooperatif dikenal sebagai pemimpin dengan ciri khas asli Indonesia.

Adapun yang dimaksud dengan kepemimpinan ciri khas Indonesia, yaitu kepemimpinan yang menghayati jiwa Pancasila, berwibawa, dan daya untuk membawa serta mengamalkan nilai Pancasila dalam menjalankan tampuk kepemimpinannya. Kepemimpinan berciri khas Indonesia ini akan mengarahkan masyarakat yang dipimpinnya pada kehidupan bernegara yang berlandaskan pada Pancasila dan Undang-Undang Dasar 1945. Berikut asas utama kepemimpinan Pancasila adalah:

a. Ing ngarso sung tulodho; sosok seorang pemimpin seyogianya memiliki sikap dan perbuatan yang dapat diteladani serta menjadi panutan bagi orang-orang yang dipimpinnya.

b. Ing madyo mangun karso; sosok seorang pemimpin semestinya dapat berperan sebagai penggerak, motivator dan mentor yang mendorong orang-orang yang dipimpinnya berswakarsa dan berkreasi. 
224 Radif Khotamir Rusli \& Hasbi Indra

Konsep Manusia dalam Epistemologi Kepemimpinan

c. Tut wuri handayani; sosok seorang mendampingi serta memberikan dorongan moral kepada orangorang yang berada dalam kepemimpinannya dari belakang.

Norma-norma kepemimpinan lain yang akan mendukung pelaksanaan ketiga asas kepemimpinan Pancasila diatas dan juga sesuai dengan nilai-nilai luhur Pancasila yakni berwibawa yang dilandasi oleh nilai-nilai luhur Pancasila, bersikap jujur, amanah, memancarkan kebijaksanaan, mampu mengayomi, berani, mawas diri, berorientasi pada masa depan, mampu menghadapi hambatan, sederhana dan mampu mempertanggungjawabkan keputusan yang diambil.

Kepemimpinan (Leadership) adalah salah satu faktor organisasi, atau sebagai salah satu fungsi manajemen, oleh karena itu merupakan masalah yang sentral dan strategis (Soekarso, 2015). Dalam hal ini (Davis, 1951) mengemukakan; "Organization is any group of individuals that is work toward zone common end under leadership" berarti sekelompok orang yang berusaha menuju arah tujuan yang sama dan wilayah yang sama tentu akan memerlukan sebuah kepemimpinan. Maka, kepemimpinan pada dasarnya mempunyai peran yang amat vital dan sifatnya strategis dalam aspek kehidupan, sebagaimana organisasi tanpa pemimpin bagaikan kapal tanpa nahkoda. Pemimpin akan menetapkan arah tujuan dengan mengembangkan suatu visi dan misi masa depan, mengorganisasi orang, dan mengelola perubahan atau reformasi. Maju dan mundurnya sebuah organisasi dan dinamis atau statisnya, serta mati hidupnya akan sangat ditentukan oleh keberadaan seorang pemimpin.

Dalam berorganisasi seorang pemimpin memiliki kekuasaan dan politik. Kekuasaan (power) merupakan kekuatan untuk menggerakkan, memberdayakan, mengarahkan, mendapatkan, memanfaatkan, dan menguasai sumber daya enam $M$, yaitu a. Men (Manusia), b. Money (Uang), c. Materials (Materia tau bahan), d. Machines (Mesin), e. Methodes (Metode), dan f. Markets (Pasar).

Di sinilah, perilaku atau gaya pemimpin akan menentukan perilaku 
p-ISSN 2579-4876 | e-ISSN 2579-3470 225

DOI: $10.30997 / j t m . v 4 i 2.3084$

organisasi, dan kepemimpinan yang efektif akan berperan serta memberikan kontribusi yang dominan dalam motor organisasi yang selalu berinteraksi dengan lingkungan berubah secara terus-menerus, baik dalam lingkungan internal, eksternal maupun global.

Kepemimpinan semestinya efektif agar pencapaian sasaran dan efisiensi pengunaan sumber daya untuk keberhasilan pencapaian tujuan. Dalam hal ini penggunaan teknik-teknik manajemen partisipatif menjadi lebih penting dalam mengelola efektivitas untuk maksimalisasi output (hasil), dan efisiensi untuk minimalisasi input (biaya).

\section{Menurut Anthony dan}

Govindarajan (Anthony, R., and V. Govindarajan, 2001) mengemukakan bahwa efektivitas kepemimpinan tergantung pada sejumlah variable:
a. pemimpin,
b. pengikut,
c. situasi, dan
d. hubungan interpersonal. (Putong, 2015)

Efektivitas kepemimpinan itu bukan ditentukan oleh seorang atau beberapa orang pemimpin saja, tetapi justru merupakan hasil bersama antara pemimpin dan orang orang yang dipimpinnya. Oleh sebab itu, seorang pemimpin tidak dapat berjalan sendiri untuh mencapai tujuan bersama. Partisipasi dari pengikutnya menjadi bagian penting dalam mencapai kepentingan bersama. Begitupun sebaliknya, bawahan tanpa pemimpin maka efektivitas pelaksanaan kewajiban dan tugasnya justru kurang optimal. Hal ini karena pemimpin berperan besar dalam mengendalikan, mengarahkan dan menciptakan suasana kondusif dalam rangkat mewujudkan kepentingan bersama.

Faktor partisipasi ini sangat menentukan dalam kepemimpinan, sehingga semakin aktif anggota kelompok organisasi dalam berpartisipasi, maka akan semakin dinamis kehidupan kelompok atau organisasi. Partisipasi dalam berpikir memecahkan masalah-masalah perlu diupayakan secara maksimal agar kepemimpinan berlangsung secara maksimal. Dalam partisipasi itu pula, akan berkembang kreativitas dan inisiatif yang menjadikan kelompok organisasi menjadi lebih aktfi, karena 
pemimpin merupakan tokoh utama dan sosok yang terbuka bagi berbagai pembaharuan, inovasi, dan perubahan yang berpengaruh pada perkembangan dan kemajuan organisasi selanjutnya.

Dalam organisasi kepemimpinan efektif, sangat dipengaruhi oleh kekuatan-kekuatan situsional, yang terhimpun melalui efektivitas dan efisiensi. Adapun indikator kinerjanya menunjukan: (1) produktivitas organisasi meningkat, (2) kepuasan kerja karyawan tinggi, dan (3) kontribusi nilai tambah (added value) bagi lingkungan berkembang.

\section{Teori-teori Kepemimpinan}

Teori kepemimpinan sejauh ini dikenal beberapa teori, sebagai berikut:

a. Teori Sifat (Traits theory) (Gehring, 2007); Metode analisa teori ini memusatkan perhatiannya pada sifat yang spesifik atau ciri dari kepribadian, sosial, fisik, dan intelektual yang membedakan antara pemimpin dan bukan pemimpin.

b. Teori Perilaku (Behavioral theory) (Conger, 1987); Metode analisa teori ini memusatkan pada karakteristik perilaku dan tindakan yang dilakukan pemimpin dalam melaksanakan peran menajerialnya.

c. Teori Kontingensi (Contingency theory) (Kriger, 2005); Metode analisa teori ini memusatkan pada hukum situasi (Law of the situation), yakni setiap situasi berbeda akan menentukan gaya kepemimpinan yang berbeda, dan berubah-ubah sesuai dengan situasi yang ada.

d. Teori Lain; yaitu pendekatan yang semakin berkembang secara campuran (hybrid), dimana metode analisa teori ini merupakan pendekatan terbaru yang mencoba memahami sesuatu situasi atau peristiwa dengan mengetahui hubungan kausalitas (sebab-akibat) antara kasus-kasus yang semakin berkembang seiring dengan perubahan fenomena yang terjadi pada organisasi.

Berdasarkan dari teori-teori yang semakin terbarukan, tentunya berdasarkan perspektif tertentu yang pada akhirnya memberikan pencerahan serta pemikiran baru. Namun, jika dikaji lebih dalam lagi, terdapat konsep yang ditawarkan oleh al-Quran dalam memandang kegigihan seorang 
p-ISSN 2579-4876 | e-ISSN 2579-3470| 227

DOI: $10.30997 /$ jtm.v4i2.3084

pemimpin dalam menghadapi kesulitan, karena setiap manusia memiliki potensi untuk bertahan dalam menghadapi setiap kesulitan dengan tipologi yang akan dibahas pada konsep berikut.

Setiap pilihan itu bermuara pada hasil tipologi manusia yang kemudian dikelompokkan kepada tiga hal. Sebagaimana disebutkan di dalam Fathir/35:32 yang artinya: "Kemudian Kitab itu Kami wariskan kepada orangorang yang Kami pilih di antara hambahamba Kami, lalu di antara mereka ada yang menganiaya diri mereka sendiri, dan di antara mereka ada yang pertengahan dan di antara mereka ada (pula) yang lebih cepat berbuat kebaikan dengan izin Allah. Yang demikian itu adalah karunia yang amat besar."

Terdapat tiga kelompok manusia yang disimpulkan dari ayat di atas:

1. Orang yang menzalimi dirinya;

2. Orang yang menjalankan sekedarnya saja;

3. Orang yang melakukan dengan sebaik-baiknya (atas izin Allah)

Terkait 3 kelompok manusia tersebut, dapatlah dikaitkan dengan Teori Advesity (Stoltz, 1997) yang menyebutkan tentang Adversity quotient $(A Q)$ adalah suatu konsep mengenai ketahanan individu dalam menghadapi berbagai kesulitan di berbagai aspek kehidupannya.

Stoltz (1997) menjelaskan konsep kecerdasan adversitas melalui analogi seorang "pendaki gunung", yang fokus mengarahkan dirinya untuk bergerak ke depan demi mencapai apapun tujuannya. Terkait dengan pendakian, ada tiga tipe individu, yaitu:

a. Quitters; merupakan tipe individu yang mudah menyerah dalam pendakian. Sikap tersebut mendorong dirinya untuk berhenti bergerak, memutuskan untuk mundur dan kemudian menyerah untuk mencapai tujuannya. Tipe quitters ini memiliki menunjukan ciri pribadi yang rendah motivasi untuk maju dan berkembang, rendak ambisi untuk mencapai tujuan dan kualitas diri di bawah standar.

b. Campers; tipe ini digambarakan sebagai seornag individu yang sesungguhnya memiliki kecerdasan adversitas dalam tingkat sedang. Individu tipe campers akan berusaha 
228 Radif Khotamir Rusli \& Hasbi Indra

Konsep Manusia dalam Epistemologi Kepemimpinan

untuk mulai mendaki, tetapi ditengah pendakian dirinya akan mudah tumbang bila menemui kesulitan. Individu dengan tipe ini cenderung memilikih untuk berhenti sejenak, menjauhkan diri dari kesulitan yang dihadapinya. Individu dengan tipe ini pula memiliki karakteristik yang penuh perhitungan bila dihadapkan pada pekerjaan yang tinggi kreativitas dan resiko yang tidak terlalu sulit. Karena dirinya cenderung menghindari resiko, maka individu dengan tipe ini berusaha untuk tetap berada di zona nyaman, merasa cukup puas dengan pencapainnya yang cenderung stagnan, tidak berani mengambil resiko besar sehingga lebih banyak mengorbankan kesempatan untuk berkembangan ke arah yang lebih baik. Berdasarkan karakteristik tersebut tipe campers memiliki motivasi yang rendah untuk mengembangkan diri dan tidak segan berhenti berusaha ditengah upaya mencapai tujuan. Dalam dunia kerja, tipikal individu campers menunjukkan sejumlah inisiatif, sedikit semangat, dan usaha alakadarnya.

c. Climbers; tipe ini menggambarkan seorang individu yang memiliki kecerdasan adversitas tinggi. Individu dengan pribadi sebagai pemikir yang selalu berusaha mencari-cari berbagai peluang, dan tidak membiarkan hambatan lainnya menghalanginya. Individu seperti ini menjalani hidupnya secara paripurna dan selalu menyambut kesulitan sebagai sebuah tantangan yang harus dijawab, yang pada akhirnya mereka sering optimis bahwa ada hal yang jauh lebih besar daripada diri mereka. Keyakinan tersebut pada dasarnya mendorong mereka untuk tetap bertahan dalam menghadapi hambatan yang menghadang, sehingga menjadi sangat gigih, ulet dan tabah. Individu dengan tipe climbers tetap teguh pada tujuan yang ingin dicapai, terus berjuang, giat bekerja keras, dan giat mencari colusi guna memecahkan masalah yang dihadapi. Namun sesungguhnya mereka tahu saat yang tepat bagi 
p-ISSN 2579-4876 | e-ISSN 2579-3470 229

DOI: $10.30997 /$ jtm.v4i2.3084

dirinya untuk berhenti sejenak dan melakukan introspeksi diri untuk kemudian kembali berjuang mencapai tujuan. Berdasarkan hal tersebut, mereka menunjukan bahwa dirinya merupakan pribadi yang memiliki kematangan dan kebijaksanaan yang melandasi pemahaman bahwa pada kondisi tertentu seorang manusia dengan segala ketidaksempurnaan yang ada pada dirinya membutuhkan waktu untuk mundur sejenak dan mempersiapkan kembali strategi untuk bergerak maju. Oleh sebab itu, mereka memiliki keberanian untuk mengambil resiko dan menghadapi tantangan, meminimalisir rasa takut, fokus pada visi, berjiwa pemimpin, dan tidak Lelah untuk bekerja keras hingga pekerjaannya selesai.

Paparan mengenai tipe individu diatas pada dasarnya menguraikan bagaimana individu pada tiap tipe merespon situasi sulit dan berusaha mencapai kesuksesa. Pada praktiknya tipe-tipe individu tersebut tidak bersifat stagnan, hal ini karena dalam proses kehidupan manusia besar kemungkinan terdapat faktor-faktor yang mendorong terjadinya perubahan tipe individu ke tipe yang lainnya sesuai dengan kemampuan adaptasi individu tersebut.

\section{SIMPULAN}

Dibandingkan dengan makhluk lain manusia diciptakan jauh lebih sempurna. Ia dilengkapi dengan kemampuan fisik dan spiritual. kemampuan spiritualnya memungkinkan manusia untuk dapat mengenali Allah dan menyembah-Nya, sedangkan kemampuan fisik adalah wadah spiritual, sehingga ada tempat untuk semangat untuk menetap. Manusia sejak proses pembuatan dilengkapi dengan "iman" yang memungkinkan dia untuk dengan mudah memahami perintah Allah dan menaatinya. Manusia diberi pikiran yang memungkinkan dia untuk mampu membedakan antara benar dan salah. Manusia diberikan hati nurani yang memungkinkan dia untuk mengenali apa yang di luar indra. Manusia selalu dijaga oleh dua malaikat yang menjaga dia dari depan dan belakang, yang 
230 Radif Khotamir Rusli \& Hasbi Indra

Konsep Manusia dalam Epistemologi Kepemimpinan

memungkinkan manusia untuk Stoltz dengan Konsep Adversitas yang

menjadi aman dari bencana dan dapat menganalisis kemampuan

kesusahan. Manusia selalu diawasi oleh seseorang dalam menghadapi

dua malaikat dengan notebook amal, kesukaran, baik kesukaran dalam

yang akan melaporkan kepada Allah belajar, maupun dalam mencapai suatu

sehingga ia dapat kembali. Semua yang kesuksesan (Adversity Quotients)

membedakan manusia dari hewan dan

Allahu a'lam

makhluk lain yang ada di alam semesta

ini. Sehingga dengan demikian,

manusia sebagai makhluk sosial,

tentunya memiliki potensi besar untuk secara naluriah alamiah menjadi

pemimpin, memimpin dirinya sendiri dan sekelompok orang tertentu, jika dalam keluarga dia akan menjadi ayah, ibu atau kakak yang akan menjadi role model (teladan) bagi siapapun yang berada di bawah naungan. Maka, dengan demikian diperlukan tips dan trik untuk menentukan model kepemimpinan seperti apa yang hendak dilakukan.

Manusia memiliki tiga pilihan; apakah dia akan melawan qodratnya (zhalim linafsih), atau hanya menjalankan hidup sekedarnya saja (muqtashid), atau justru melakukan tugas dengan sebaik-baiknya (sabiq bilkhairat). Tiga kriteria pilihan manusia yang kemudian diadopsi oleh Paul

\section{DAFTAR PUSTAKA}

Al-Quran al-karim dan Terjemahnya, Khadim al-Haramain asy-Syarifain, Departemen Agama Republik Indonesia.

Abdullah, Salhah, and Ainon Mohd. (2005). Guru sebagai mentor. Kuala Lumpur: PTS Professional.

Adair, J. (2007). Cara Menumbuhkan Pemimpin (Alih Bahasa: Said Bazry). Jakarta: Gramedia Pustaka Utama. Aditya, Purwa, I. Made Pageh, and Ketut Sedana Arta. (2017). Biografi I Ketut Widjana (Perjuangan, NilaiNilai Kepahlawanan dan Potensinya Sebagai Sumber Belajar Sejarah. Widya Winayata: Jurnal Pendidikan Sejarah, 7(1).

Amin, Surahman, and Ferry M. Siregar. (2015). Pemimpin dan Kepemimpinan dalam al-Qur'an. Tanzil: Jurnal Studi Al-Qur'an, 1(1), 27.

Aminah, S. (2018). Komunikasi Pemimpin dalam Strategi Positioning guna Meningkatkan Daya Saing Perguruan Tinggi Islam. Indonesian Journal of Islamic Communication, 1(1), 26-50.

Ardianto, A., Prisanto, G. F., Irwansyah, I., Ernungtyas, N. F., \& Hidayanto, S. (2020). Praktik Lobi dan Negosiasi oleh Legislator 
p-ISSN 2579-4876 | e-ISSN 2579-3470

Sebagai Bentuk Komunikasi Politik. Komuniti: Jurnal Komunikasi dan Teknologi Informasi, 12(1), 25-39. Aryani, L., Marettih, A. K. E., Cucuani, H., Susanti, R., \& Lestari, Y. I. (2013). Kompetensi Tidak Sempurna Tanpa Integritas Pada Pemimpin. Jurnal Psikologi, 9(1), 3139.

Adair, J. (2007). Cara Menumbuhkan Pemimpin. Jakarta: Gramedia Pustaka Utama.

Baswedan, A. (2013). Surat dari E untuk pemimpin: menjadi Indonesia. (A. Loebis, Ed.) Jakarta: Tempo Publishing.

Budiono, B. (2012). Dedikasi dan Loyalitas Pengabdian Pelatih Yang Berkarakter Untuk Indonesia. Jorpres (Jurnal Olahraga Prestasi), 8(2), 102-107.

Conger, J. A. (1987). Toward a behavioral theory of charismatic leadership in organizational settings. Academy of management review, 12(4), 637-647.

Davis, R. C. (1951). The Fundamentals of Top Management. Harper: University of California.

Dahlan, D. (t.t.). Start Young. Tips \& Trik Sukses di Usia Muda, Jakarta: Grasindo Gramedia.

Faturahman, B. M. (2018).

Kepemimpinan dalam Budaya Organisasi. MADANI Jurnal Politik dan Sosial Kemasyarakatan, 10(1), 111.

Fitriyah, Nurul, and Agus Suliyadi. (2018). Membangun Kompetensi Pemimpin dalam Mengelola Organisasi Publik: Strategi dan Aplikasi. Madani Jurnal Politik Dan Sosial Kemasyarakatan, 10(1), 79-91.
Gehring, D. R. (2007). Applying Traits Theory of Leadership to Project Management. Project Management Journal, 38(1), 44-54.

Gillinson, S. (2004). Why Cooperate?: A Multi-disciplinary Study of Collective Action. London: Overseas Development Institute.

Hasibuan, M. S. (2016). Manajemen sumber daya manusia. Bumi Aksara.

Kartakusumah, B. (2006). Pemimpin Adiluhung: Genealogi Kepemimpinan Kontemporer. Teraju.

Kriger, M. a. (2005). Leadership with inner meaning: A contingency theory of leadership based on the worldviews of five religions. The leadership quarterly, 16(5), 771-806.

Mahmudin, Shafwan, and Trisni Andayani. (2017). Eksistensi Silek Galombang Pada Upacara Perkawinan Etnis Minangkabau Di Medan. Gondang: Jurnal Seni dan Budaya, 1(2), 78-90.

Mahessa, Nurul Fathia, and N. R. H. Frieda. (2017). Gaya Kepemimpinan Melayani Dan Kesiapan Untuk Berubah Pada Karyawan BPJS Ketenagakerjaan. 5(1), 113-116.

Marwah, M. (2018). Umar Bin Khattab: Potret Keteladanan Sang Pemimpin Umat. AL-TADABBUR, 4(2), 1-20.

Ni'mah, M. (2015). Transformasi Selebriti Menjadi Politisi: Urgensi Personal Front dalam Ranah Sosial. Informasi, 45(2), 141-154.

Nurhayati, S. (2014). Mambangun Kepemimpinan Yang Efektif Untuk Meraih Keunggulan Kompetitif Organisasi. Jurnal Ekonomi Dan Bisnis, 15(2), 21-27.

Othman, Norasmah, Siti Junaidah M. Mujir, and Mohammed Sani Ibrahim. (2012). Pengaruh Persepsi 
Radif Khotamir Rusli \& Hasbi Indra

Konsep Manusia dalam Epistemologi Kepemimpinan

Terhadap Keberkesanan

Kepimpinan ke Atas Orientasi

Kepimpinan Multidimensi

Pemimpin Akademik dan

Komitmen Pensyarah. UKM Journal

of Management, 34.

Pratasik, R. R. (2013). Analisis

Pemberdayaan, Motivasi, dan

Produktivitas Kerja Pengrajin

Meubel di Desa Leilem Tiga

Kecamatan Sonder Kabupaten

Minahasa. Jurnal EMBA: Jurnal

Riset Ekonomi, Manajemen, Bisnis

dan Akuntansi, 1(4).

Putong, I. (2015). Kepemimpinan: kajian teoritis dan praktis. Vol. 1.

Buku\&Artikel Karya Iskandar

Putong.

Rodliyah, S. (2019). Leadership

Pesantren: Urgensi Pendidikan

dalam Menyiapkan Pemimpin

Bangsa Berkualitas dan Bermoral.

MANAGERIA: Jurnal Manajemen

Pendidikan Islam, 4(1), 169-182.

Rohmat, D. (2016). Relasi

Kepemimpinan dan Kultur

Sekolah. Jurnal Kependidikan

INSANIA, 21(2), 161-178.

Shihab, M. Quraish. "Wawasan AlQuran." Bandung: Mizan (1996).

Soekarso, I. P. (2015). Kepemimpinan: Kajian Teoritis dan Praktis (Vol. 1). (C. Hidayat, Ed.) Buku\&Artikel Karya Iskandar Putong.

Sridiyatmiko, G. (2019). Pribadi Sri Sultan Hamengkubuwana IX Sebagai Sosok Inspiring bagi Bangsa Indonesia dan Nilai-Nilai Ke-IPS-an yang Terkadung di dalamnya. Jurnal Sosialita, 11(1), 167-187.

Stoltz, P. G. (1997). Adversity quotient:

Turning obstacles into opportunities. USA: John Wiley \& Sons.
Sumarni, Sri, Achmad Dardiri, and Darmiyati Zuchdi. (2015).

Pengembangan Model Pendidikan

Karakter Berbasis Penguatan

Modal Sosial Bagi Mahasiswa UIN

Sunan Kalijaga. Jurnal Pembangunan

Pendidikan: Fondasi dan Aplikasi, 3(1), 44-57.

Syahrul, S. (2015). Kepemimpinan dan

Inovasi Lembaga Pendidikan

(Pengalaman Pondok Gontor VII

Putra Sulawesi Tenggara). Al-

Ta'dib, 8(1), 82-100.

Van Knippenberg, Barbara, and Daan

Van Knippenberg. (2005). Leader

self-sacrifice and leadership

effectiveness: the moderating role

of leader prototypicality. Journal of

applied psychology, 90(1), 25.

Widayat, P. A. (2014). Kepemimpinan

Profetik. Jurnal Pemikiran Islam, 19(1), 18-34.

Widyawati, Karya, Atie Ernawati, and

Fanty Puspita Dewi. (2015).

Peranan Ruang Terbuka Publik

Terhadap Tingkat Solidaritas dan

Kepedulian Penghuni Kawasan

Perumahan di Jakarta. Faktor

Exacta, 4(3), 246-260.

Yahya, Harun, (2003), Keajaiban Penciptaan Manusia . (CD-ROM), Jakarta: Okur

Production

Yuwana, R. Y. (2019). Strategi penciptaan materi humor: Analisis transitivitas. LEKSEMA: Jurnal Bahasa dan Sastra, 4(1), 1-10.

Yuliana, Baiturrohma, and Isro Ani Widayati. (2018). Analisis

Karakteristik Pemimpin Yang

Dikagumi Oleh Bawahan. Jurnal

Ilmiah Administrasi Bisnis dan

Inovasi, 2(1), 209-218. 